\title{
Frequency of CCR5- $\Delta 32$ deletion in human immunodeficiency virus type 1 (HIV-1) in healthy blood donors, HIV-1-exposed seronegative and HIV-1-seropositive individuals of southern Brazilian population
}

\author{
EDNA MARIA VISSOCI REICHE ${ }^{1}$, MARIA ANGELICA EHARA WATANABE ${ }^{2}$, ANA MARIA BONAMETTI $^{1}$, \\ HELENA KAMINAMI MORIMOTO ${ }^{1}$, ARILSON AKIRA MORIMOTO ${ }^{1,3}$, SUSANA LÍLIAN WIECHMANN ${ }^{1}$, \\ TIEMI MATSUO ${ }^{4}$, JAQUELINE CARVALHO DE OLIVEIRA ${ }^{2}$ and FERNANDO VISSOCI REICHE ${ }^{1}$ \\ ${ }^{1}$ Health Sciences Center, University Hospital of Londrina, Londrina State University, Av. Robert Koch, 60, \\ CEP 86.038-440; ${ }^{2}$ Biological Sciences Center, Londrina State University, Rodovia Celso Garcia Cid, Km 380, s/n, \\ CEP 86051-890; ${ }^{3}$ Integrated Center of Infectious Diseases, Londrina, Health State Secretariat of the State Paraná, \\ Brazil, Al. Manoel Ribas, 1, CEP 86010-140; ${ }^{4}$ Exact Sciences Center, Londrina State University, \\ Rodovia Celso Garcia Cid, Km 380, s/n, CEP 86051-890, Londrina, Paraná, Brazil
}

Received June 18, 2008; Accepted August 1, 2008

DOI: 10.3892/ijmm_00000071

\begin{abstract}
The frequency of CCR5- $\Delta 32$ allele in human immunodeficiency virus type 1 (HIV-1) infection in the southern Brazilian population was determined in a crosssectional study carried out from October 2001 to June 2004. Genomic DNA was extracted from peripheral blood cells of 134 healthy blood donors, 145 HIV-1-exposed seronegative individuals, $152 \mathrm{HIV}$-1-seropositive asymptomatic individuals, and $478 \mathrm{HIV}$-1-seropositive individuals with AIDS. A fragment with 225 base-pairs of the CCR5 gene was amplified by polymerase chain reaction. The CCR5- $\Delta 32$ homozygous deletion was observed in $2(1.5 \%)$ blood donors and in 1 $(0.7 \%)$ individual HIV-1-exposed seronegative, and was absent among all the HIV-1-seropositive individuals (Fisher's exact test, $\mathrm{p}=0.0242$ ). The frequency of the homozygous CCR5- $\Delta 32$ deletion in the HIV-1-exposed did not differ when compared with that observed in the HIV-1 seronegative blood donors (Fisher's exact test, $\mathrm{p}=0.6093$; OR: $2.18,95 \%$ CI: 0.11-129.6). The wild-type genotype CCR5/CCR5 frequency was higher among the HIV-1-seropositive with AIDS compared to HIV-1 seropositive asymptomatic individuals (Chi-square test, $\mathrm{p}=0.0263$; OR: 2.02 , 95\% CI:
\end{abstract}

Correspondence to: Dr Edna Maria Vissoci Reiche, Health Sciences Center, Department of Pathology, Clinical Analysis and Toxicology, University Hospital of Londrina State University. Av. Robert Koch, 60, Vila Operária, CEP 86.038-440, Londrina, Paraná, Brazil

E-mail: reiche@sercomtel.com.br

Key words: genetic polymorphism, chemokine receptor, CCR5- $\Delta 32$ allele, human immunodeficiency virus type 1 , AIDS
1.03-3.97). The absence of the homozygous deletion of CCR5- $\triangle 32$ among HIV-1-seropositive individuals underscored that this genotype is an important genetic factor associated with the decreased susceptibility to HIV-1 infection. The higher frequency of heterozygosity for the CCR5- $\Delta 32$ and the CCR5- $\Delta 32$ allele in HIV-1 seropositive asymptomatic compared to HIV-seropositive with AIDS individuals also underscored that this deletion could be associated with the delay of the HIV-1 disease progression in this population. However, the low frequency of CCR5- $\Delta 32$ homozygosity observed among HIV-1-exposed seronegative individuals shows that the allele could not explain, by itself the natural resistance to HIV-1 infection and different mechanisms of protection against HIV-1 infection that must be involved in this population.

\section{Introduction}

The natural history and pathogenic processes of infection by the human immunodeficiency virus type 1 (HIV-1) are complex, variable, and the ability to control the infection and to delay the progression to AIDS and/or death is probably regulated by a balance between host and viral factors (1-5). Human allelic variants influence not only the susceptibility to HIV-1 infection but also the subsequent rates of disease progression towards AIDS. The deletion of 32-base-pairs in the chemokine receptor 5 gene (CCR5- $\Delta 32)$ was the first and most well characterized host restriction allele associated with a high degree of protection against HIV-1 infection (6). Homozygous individuals for CCR5- $\Delta 32$ allele have been found to be resistant to HIV-1 infection, while the heterozygous can significantly delay the onset of AIDS. This deletion creates a shortened protein which remains intracellular and fails to reach the cell surface in homozygous individuals for this variant. Although the heterozygosity was not related to 
the complete protection against HIV-1 infection $(6,8)$, it may confer partial protection against disease progression or death in HIV-1 infected individuals (9-16). Heterozygosity for the CCR5- $\Delta 32$ deletion is significantly higher in cohorts of HIV-1 infected long-term non-progressors (LTNP) compared to HIV-1 infected typical progressor individuals $(9,17,18)$.

The global, ethnic and regional distribution of the CCR5$\Delta 32$ allele varies significantly giving each population a different genetic resistance profile to the HIV-1 infection and AIDS progression (19). The CCR5- $\Delta 32$ allele is relatively common in Caucasians whose allelic frequency is $\sim 10 \%$, and homozygosity is found in $1 \%$ of Caucasian blood donors (20). The CCR5- $\Delta 32$ deletion is prevalent in European populations with wide variation of $10-20 \%$ and almost absent from Asian groups (8). The frequency of this deletion was observed with a gradient, uppermost at the north around the Baltic Sea down to the Mediterranean coast (21). In Europeanderived populations from the US and Southern Europe, CCR5$\Delta 32$ was observed at a frequency of $5-10 \%$, but decreased to $2-5 \%$ in Hispanic populations, throughout the Middle East or in the Indian continent. This allele is almost absent among African-Americans in whom admixture with people of European descent has been considerable (20). In Asian populations, the CCR5- $\Delta 32$ allele was absent among Japanese, Filipino, Korean, Chinese and Indian populations studied (22), and healthy Thai blood donors (23). No $\Delta 32 / \Delta 32$ genotype was detected among normal individuals from south of Iran (24), and from Arabic countries such as Egyptians and Syrians (25).

In some countries of Latin America, the frequency of the CCR5- $\triangle 32$ allele was $5.3 \%$ and absent among individuals from Venezuela or in Amerindian $(20,26)$. In Brazil, studies of the CCR5 genotypes carried out in urban unrelated healthy individuals found $93.0 \%$ of wild-type CCR5/CCR5 homozygotes, $7.0 \%$ of CCR5/ $\Delta 32$ heterozygotes, and absence of homozygous $\Delta 32 / \Delta 32$ individuals, resulting in an allelic frequency of 0.035 (27). Further, the absence of CCR5- $\Delta 32$ allele was also observed in Amerindians from four Brazilian Amazon tribes. All the individuals were homozygous for the wild-type allele, which correlates to the hypothesis that the CCR5- $\triangle 32$ allele has an European origin, and that its occurrence in urban populations in South America is the result of immigration (28). Among HIV-1 seronegative and HIV-1 infected individuals from northeast Brazilian region, the CCR5$\Delta 32$ allelic frequency was 0.026 and 0.044 , respectively; among German-descended healthy blood donors from southern region was 0.065 ; and was absent among individuals of two Amerindian tribes from north region (29). Another study carried out in unrelated healthy individuals from southern Brazilian region, no homozygotes for the CCR5- $\Delta 32$ deletion were detected (30).

The HIV-1 epidemic is increasing in Brazil, where over 620,000 (370,000 to one million) people living with HIV-1 were identified (31). Up to June 2006, a total of 433,067 cases of AIDS had been reported in Brazil, and the southern state of Paraná has the fifth highest incidence of AIDS in the country, with 20,176 cases (32). However, previous studies involving the CCR5- $\triangle 32$ allele and HIV-1 infection evaluated a small number of individuals. The present study was carried out in order to determine the frequency of CCR5- $\Delta 32$ allele in a large Brazilian sample of healthy blood donors, HIV-1exposed seronegative individuals, and HIV-1-seropositive individuals in various stages of HIV-1 infection.

\section{Materials and methods}

Participants and design. The protocol was approved by the Institutional Research Ethics Committees of Londrina State University and of the Health State Secretariat of Paraná, in southern Brazil. Individuals were invited to participate and informed in detail about the research, and their written consent was obtained. The sample evaluated was available from previous studies carried out from October 2001 to June 2004 and were described previously (33-35). For the CCR5 genotype study, a cross-sectional study was carried out and 909 individuals were enrolled. All of them were classified into self-described racial characteristics and distributed into four groups:

Blood donors. One hundred and thirty-four healthy HIV-1 seronegative individuals recruited from faithful and repeatedly screened blood donors of the Blood Bank of the University Hospital of Londrina, Paraná state, with a number of previous blood donations ranging from 2-17 (4.4 2.6$)$. They were considered to be at low risk of HIV-1 infection according to the risk-screening strategies for determining individuals at risk for HIV-1 infection (36).

HIV-1-exposed but seronegative. One hundred and forty-five HIV-1-exposed individuals but seronegative after $\geq 2$ consecutive anti-HIV-1 antibody tests by immunological assays. The individual risk was determined through risk screening based on self-report behavioral risks (36). All the 145 individuals had high exposure to HIV-1 infection through repeatedly unprotected sexual intercourse with a known HIV-1-infected partner for at least 2 years prior to the present study. Fifty individuals also reported repeated exposure ( $\geq 3$ episodes) to blood infected with HIV-1 infection by sharing equipment for injectable drug use (needles, syringes, cotton, water) with HIV-1-seropositive individuals. All participants were advised on safe-sex practice.

HIV-1-seropositive asymptomatic. One hundred and fifty-two HIV-1-seropositive individuals, asymptomatic and with $\mathrm{CD}^{+}$ T-cell counts $\geq 350$ cells $/ \mathrm{mm}^{3}$. The most frequent risk factor for HIV-1 infection was sexual contact $(n=142)$. Other risk factors also reported were blood contact by sharing equipment for injectable drug use (needles, syringes, cotton, water) with HIV-1-seropositive individuals or blood transfusion, and accident with blood $(n=20)$. Some individuals reported more than one risk factor for HIV-1 infection. At the time of enrollment, $98(64.5 \%)$ subjects were receiving no antiretroviral therapy, and $54(35.5 \%)$ were on antiretroviral therapy, according to the Brazilian guidelines that were used at that time (37).

HIV-1 seropositive with AIDS. Four hundred and seventy-eight HIV-1-seropositive individuals with the symptoms of the disease and/or CD4 ${ }^{+} \mathrm{T}$-cell counts $<350$ cells $/ \mathrm{mm}^{3}$, according to the Brazilian government criteria definition (38). The most 
Table I. Frequency (\%) of CCR5- $\Delta 32$ deletion according to the race of the HIV-1-seronegative and HIV-1-seropositive individuals from a southern Brazilian population.

\begin{tabular}{|c|c|c|c|c|c|}
\hline CCR5 genotypes ${ }^{\mathrm{a}}$ & $\begin{array}{c}\text { Caucasians } \\
(\mathrm{n}=635)\end{array}$ & $\begin{array}{l}\text { Mullatoes } \\
(\mathrm{n}=214)\end{array}$ & $\begin{array}{l}\text { Blacks } \\
(\mathrm{n}=55)\end{array}$ & $\begin{array}{c}\text { Asians } \\
(\mathrm{n}=5)\end{array}$ & $\begin{array}{c}\text { Total } \\
(\mathrm{n}=909)\end{array}$ \\
\hline CCR5/CCR5 & $574(90.4)$ & $202(94.4)$ & $55(100.0)$ & $5(100.0)$ & $836(92.0)$ \\
\hline $\mathrm{CCR} 5 / \triangle 32$ & $58(9.1)$ & $12(5.6)$ & $0(0.0)$ & $0(0.0)$ & $70(7.7)$ \\
\hline$\Delta 32 / \Delta 32$ & $3(0.5)$ & $0(0.0)$ & $0(0.0)$ & $0(0.0)$ & $3(0.3)$ \\
\hline CCR $5 / \Delta 32$ allele frequency & 0.0504 & 0.0280 & 0 & 0 & 0.0418 \\
\hline
\end{tabular}

${ }^{a} C C R 5 / C C R 5$, wild-type genotype; CCR5/ $\Delta 32$, heterozygous genotype for the deletion; $\Delta 32 / \Delta 32$, homozygous genotype for the deletion Fisher's exact test, $\mathrm{p}=0.077$.

frequent risk factor for HIV-1 infection was sexual contact $(n=420)$; blood contact by sharing equipment for injectable drug use (needles, syringes, cotton, water) with HIV-1seropositive individuals, blood transfusion, accident with blood, vertical transmission, and tattoo $(n=89)$. Some individuals also reported more than one risk factor for HIV-1 infection. At the time of enrollment, 104 (21.7\%) subjects were receiving no antiretroviral therapy, $374(78.3 \%)$ were on antiretroviral therapy, according to the Brazilian guidelines that were used at that time (37).

The HIV-1-exposed seronegative and the HIV-1seropositive individuals were enrolled in several specialized, public, and nonprofit centers for diagnosis and treatment of STD, including University Hospital of Londrina State University; Outpatient Clinic Hospital of Londrina State University; Integrated Center of Infectious Diseases of Londrina, and the Health Services of several cities from Paraná state, southern Brazil. These individuals presented relative homogeneity in demographic characteristics such as gender, age, risk factors for HIV-1 infection, route of transmission of the HIV-1, access to free health care and relatively uniform clinical, diagnostic procedures, and treatment patterns for the HIV-1 infection, as described previously (33-35).

Serological, and immunological assays. The serological screening tests used were enzyme immunosorbent assay (ELISA, Murex ${ }^{\mathrm{TM}}$ HIV-1.2.0, Murex Biotech Limited, Dartford, UK), and microparticle enzyme-immunoassay (MEIA, Abbott Axsym ${ }^{\mathrm{TM}}$ System, HIV-1/2 gO, Abbott $\mathrm{GmbH}$, Weisbaden, Germany). The confirmatory tests used were indirect immunofluorescence (slides from Fiocruz Institute, Rio de Janeiro, Brazil) and Western blot analysis (Genelabs Diagnostics, Singapore). Both screening and confirmatory tests were performed according to the Brazilian government standard procedures (39). The first determination of $\mathrm{CD}^{+}$and $\mathrm{CD}^{+} \mathrm{T}$-cell counts, obtained after the date of enrollment, was performed for 909 individuals by flow cytofluorimetry (FACSCount ${ }^{\mathrm{TM}}$, Becton, Dickinson and Company, San Jose, CA) and the results were recorded as number of cells $/ \mathrm{mm}^{3}$.

CCR5 genotyping. The CCR5 genotypes were determined by polymerase chain reaction (PCR) as previously described
$(6,13)$. Briefly, a peripheral blood sample was collected, with EDTA as anticoagulant. Mononuclear cells were separated by Ficoll-Hypaque (Sigma, St. Louis, MO) gradient. Genomic DNA was extracted using the salting out method described elsewhere (40). The following primers were used from the previously published sequences (GenBank accession no.: AF 009962): primer sense: 5'-ACCAGATCTCAAAAA GAA-3' and primer anti-sense: 5'-CATGATGGTGAAGA TAAGCTTCA-3'. For amplification, a total volume of $25 \mu 1$, containing $2.0 \mu \mathrm{l}(100 \mathrm{ng})$ of genomic DNA, $1.5 \mu \mathrm{l}(2.5 \mu \mathrm{M})$ of each primers, $2.0 \mu \mathrm{l}(1,25 \mu \mathrm{M})$ of dNTPs mix (Invitrogen $^{\text {TM }}$ Life Technologies, Carlsbad, CA), $0.75 \mu 1 \mathrm{MgCl}_{2}(50 \mu \mathrm{M})$, $2.5 \mu 110 \mathrm{X}$ PCR buffer (500 mM KCl and $200 \mathrm{mM}$ Tris- $\mathrm{HCl}$, $\mathrm{pH} 8.4$ ), $2.5 \mu 1$ (2 units) of Taq DNA polymerase (Invitrogen Life Technologies), $12.25 \mu \mathrm{l}$ of sterile water, and 2.0 were used. PCR was performed for 35 cycles (Hybaid Sprint ${ }^{\mathrm{TM}}$ thermocycler, Biosystems, Barcelona, Spain), each consisting of denaturation at $94^{\circ} \mathrm{C}$ for $1 \mathrm{~min}$, annealing at $58^{\circ} \mathrm{C}$ for $1 \mathrm{~min}$ and extension at $72^{\circ} \mathrm{C}$ for $1 \mathrm{~min}$. Pre-denaturation and further extension were performed at $94^{\circ} \mathrm{C}$ for $5 \mathrm{~min}$ and $72^{\circ} \mathrm{C}$ for $10 \mathrm{~min}$, respectively. The PCR products of 225 basepair fragment from wild-type allele and of 193 base-pair fragment from the deleted allele were analysed by $3 \%$ agarose gel electrophoresis and visualized by UV fluorescence after staining with ethidium bromide. Ambiguous results were resolved by performing electrophoresis of the PCR products in a $10 \%$ acrylamide gel, and the gel stained with silver. In each experiment reaction, both control amplification containing no added DNA and positive control containing known CCR5 wild-type genotype were included. The images of the gel were captured and recorded with the Digit-Doc-It Program version 1.1.25.

Statistical analysis. A database with the results was set up using the EPI INFO software version 6.04d (41) and SAS Program (42). Comparisons between race were performed using the Fisher's exact test. In this study, two main hypotheses were tested. The first was that homozygosity for the CCR5- $\triangle 32$ deletion would be higher among HIV-1-exposed seronegative individuals compared to HIV-1 seronegative blood donors. The second was that the wild-type genotype (CCR5/CCR5) frequency would be higher in HIV-1 seropositive with AIDS compared to HIV-1-seropositive asymptomatic individuals. 
Table II. Distribution of the CCR5 genetic polymorphism and frequency of CCR5- $\Delta 32$ deletion in HIV-1-seronegative and HIV-1-seropositive individuals from a southern Brazilian population.

\begin{tabular}{|c|c|c|c|c|}
\hline \multirow[b]{2}{*}{ CCR5 genotype ${ }^{a}$} & \multicolumn{2}{|c|}{ HIV-1 seronegative } & \multicolumn{2}{|c|}{ HIV-1 seropositive } \\
\hline & $\begin{array}{l}\text { Blood donors } \\
\quad(n=134)\end{array}$ & $\begin{array}{l}\text { HIV-1-exposed } \\
\qquad(n=145)\end{array}$ & $\begin{array}{l}\text { Asymptomatic } \\
\qquad(n=152)\end{array}$ & $\begin{array}{l}\text { With AIDS }{ }^{d} \\
\quad(n=478)\end{array}$ \\
\hline CCR5/CCR5 & $121(90.3)$ & $130(89.7)$ & $135(94.1)$ & $450(94.1)$ \\
\hline $\mathrm{CCR} 5 / \triangle 32$ & $11(8.2)$ & $14(9.6)$ & $17(11.2)$ & $28(5.9)$ \\
\hline$\Delta 32 / \Delta 32$ & $2(1.5)$ & $1(0.7)$ & 0.0 & 0.0 \\
\hline CCR5- $\Delta 32$ allele & 0.0559 & 0.0551 & 0.0592 & 0.0290 \\
\hline
\end{tabular}

${ }^{a} C C R 5 / C C R 5$, wild-type genotype; CCR5/ $\Delta 32$, heterozygous genotype for the deletion; $\Delta 32 / \Delta 32$ : homozygous genotype for the deletion. ${ }^{b} \mathrm{HIV}$-1-exposed but uninfected sexual partners of HIV-1-infected individuals. ${ }^{\mathrm{c}} \mathrm{HIV}$-1-seropositive asymptomatic individuals and with CD4+ T-cell count $\geq 350 / \mathrm{mm}^{3}$. ${ }^{\mathrm{d}} \mathrm{HIV}$-1-seropositive individuals with the symptoms of the disease and/or $\mathrm{CD} 4^{+} \mathrm{T}$ cell count $<350 / \mathrm{mm}^{3}$. Fisher's exact test, $\mathrm{p}=0.6093$ (OR: 2.18, 95\% CI: 0.11-129.6) when the frequency of CCR5- $\Delta 32$ homozygous mutation observed in HIV-1-exposed seronegative was compared with the observed in HIV-1-seronegative blood donors; Fisher's exact test, $p=0.0287$, when the frequency of CCR5- $\triangle 32$ allele observed in all HIV-1-seronegative individuals was compared with that observed in all HIV-1-seropositive individuals; Chi-square test, $\mathrm{p}=0.0263$ (OR: $2.02,95 \%$ CI: 1.03 -3.97) when the frequency of wild-type genotype observed in HIV-1 seropositive with AIDS was compared with that observed in HIV-1-seropositive asymptomatic individuals.

The odds ratio (OR) with $95 \%$ confidence interval (CI), and Fisher's exact test was used to test the first hypothesis and Chi-square test were used to test the second hypothesis. Twotailed tests were used, and differences between groups were considered to be statistically significant at $\mathrm{p}<0.05$.

\section{Results}

Frequency of CCR5- $\triangle 32$ allele according to the race of HIV-1seronegative and $H I V-1$-seropositive individuals. In a total of 909 samples evaluated, the CCR5 genotype polymorphism distribution and CCR5- $\triangle 32$ allelic frequencies were not different when the self-reported racial characteristic of the individuals evaluated was considered (Fisher's exact test, $\mathrm{p}=0.077)$. The allelic frequency was 0.0504 among the Caucasian individuals and the CCR5- $\Delta 32$ allele was absent among the Black and Asian individuals (Table I).

Frequency of CCR5- $\triangle 32$ in HIV-1-seronegative blood donors, HIV-1-exposed seronegative and HIV-1-seropositive individuals. The frequencies of the CCR5- $\Delta 32$ deletion were 0.0559 in healthy blood donors, 0.0551 in HIV-1-exposed seronegative, 0.0559 in HIV-1 seropositive asymptomatic and 0.0292 in HIV-1 seropositivity with AIDS (Fisher's exact test, $\mathrm{p}=0.0242$ ) (Table II). Eleven (8.2\%) out of $134 \mathrm{HIV}-1$ seronegative blood donors were heterozygous and two (1.5\%) were homozygous for the CCR5- $\Delta 32$ deletion. Fourteen (9.6\%) out of $145 \mathrm{HIV}-1$-exposed seronegative were heterozygous for CCR5- $\triangle 32$ and one $(0.7 \%)$ was homozygous for the deletion. The frequency of the homozygous CCR5- $\triangle 32$ deletion in HIV-1-exposed did not differ when compared with that observed in HIV-1 seronegative blood donors (Fisher's exact test, $\mathrm{p}=0.6093$; OR: 2.18 , 95\% CI: 0.11-129.6). A comparison of the frequency of CCR5- $\triangle 32$ observed among all HIV-1-seronegative individuals versus all HIV-1-seropositive individuals showed statistical differences (Fisher's exact test, $\mathrm{p}=0.0287)$. None of the 630 HIV-1-seropositive individuals (152 asymptomatic and 478 with AIDS) was homozygous and 45 (7.1\%) were heterozygous for the CCR5- $\triangle 32$ deletion.

Comparison of the frequency of CCR5- 432 in HIV-1seropositive asymptomatic individuals versus HIV-1seropositive individuals with AIDS. Of the 152 HIV-1seropositive asymptomatic individuals that also presented $\mathrm{CD}^{+} \mathrm{T}$-cell count $\geq 350$ cells $/ \mathrm{mm}^{3}, 17$ (11.2\%) were heterozygous for the deletion and $135(88.8 \%)$ had the wildtype genotype. Of the $478 \mathrm{HIV}-1$ seropositive with AIDS and/or presented CD4 ${ }^{+} \mathrm{T}$-cell count $<350$ cells $/ \mathrm{mm}^{3}, 28(5.9 \%)$ were heterozygous for the deletion and 450 (94.1\%) had the wild-type genotype (Table II). The wild-type genotype CCR5/ CCR5 frequency was higher among HIV-1-seropositive with AIDS compared to HIV-1 seropositive asymptomatic individuals (Chi-square test, $\mathrm{p}=0.0263$; OR: $2.02,95 \% \mathrm{CI}$ : 1.03-3.97).

\section{Discussion}

This is the largest study undertaken to determine the frequency of the CCR5- $\triangle 32$ allele in a Brazilian population of healthy individuals, HIV-1-exposed seronegative individuals, HIV-1seropositive asymptomatic and symptomatic individuals. The overall frequencies of the homozygous genotype of the CCR5- $\Delta 32$ deletion and the CCR5- $\Delta 32$ allele obtained either for the total sample or for only the blood donors were consistent with data reported for other healthy populations from Latin America and Europe (6-8,10,20,21,26,27,29,43).

The overall allelic frequency of 0.418 obtained can be explained by the heterogeneous ethnic structure of the Brazilian population. Europeans, Asians, Arabians, Africans and native Amerindians that contributed to the formation of the present Brazilian population since the 16th century 
$(44,45)$. The absence of the CCR5- $\Delta 32$ homozygous genotype observed in Black and Asian people was in agreement with previous studies showing this genotype is infrequent among populations of African or Asian origins (8,20,22,23).

The similar frequency of the CCR5- $\triangle 32$ allele observed among healthy individuals and HIV-1-exposed seronegative individuals evaluated in this study, despite their different risk factors for HIV-1 infection, is consistent with the hypothesis that this allele could not explain, by itself, the natural resistance to HIV-1 infection among sexually exposed to HIV-1 but seronegative individuals. This fact underscores the existence of different mechanisms responsible for natural resistance to HIV-1 infection as suggested by other studies $(22,26,42,46,47)$. Host factors modulating viral entry such as genetic polymorphisms in other chemokine receptors or in their ligands (48), the innate and acquired cellular immune responses against HIV-1 $(3,49)$, and HLA genes $(50-52)$ have been suggested to be involved both in the resistance to HIV-1 infection and disease progression. Several groups that are at risk for HIV-1 infection but have not become infected have been reported and studies have shown that some of these persons demonstrate HIV-1-specific cytotoxic T lymphocyte (CTLs) response as well, suggesting a possible role of CTLs in preventing establishment of infection (53-59).

The absence of the homozygous for the CCR5- $\Delta 32$ deletion among HIV-1-seropositive individuals is in agreement with previous studies that showed this host as an important genetic factor associated with the decreased susceptibility to HIV-1 infection $(6,7)$. The higher frequency of heterozygosity for the CCR5- $\Delta 32$ observed in HIV-1-seropositive asymptomatic individuals than in HIV-1 seropositive with AIDS is also consistent with studies carried out in other worldwide populations. The heterozygosity was significantly higher in cohorts of HIV-1 infected LTNP compared to HIV-1 infected typical progressors $(9,17,18)$. Although the heterozygosity was not related to the complete protection against HIV-1 infection $(6,8)$, it may confer partial protection against disease progression or death in HIV-1 infected individuals (9-12,14,15). Presumably, heterozygosity limits the number of coreceptors available for HIV-1 binding. CCR5 density of the surface of the $\mathrm{CD}^{+} \mathrm{T}$-cell has been correlated with viral load in persons with untreated HIV-1 infection (60). Studies incorporating viral phenotype have suggested that the protective effect of CCR5- $\Delta 32$ heterozygosity against disease progression is lost when the infection virus is T-tropic (61).

An international meta-analysis showed that HIV-1 infected subjects heterozygous for the CCR5- $\Delta 32$ displayed lower HIV-1 RNA level than wild-type patients. This result appears to be supported by the simple explanation that fewer available CCR5 portals on cells of CCR5- $\Delta 32$ delay HIV-1 replication and the virus-mediated destruction of the $\mathrm{CD}^{+} /$ $\mathrm{CCR}^{+}$T-cell lymphocyte population (16).

The relative homogeneity of the sample evaluated may contribute to the validation of the results obtained and to strenghten the earlier observations that the effect of CCR5$\Delta 32$ mutation, by itself, may not be sufficient to prevent the risk of acquisition of the HIV-1 infection but is related to the delayed disease progression. In this post-genomic era, the observation that the naturally-occurring genetic CCR5- $\Delta 32$ mutation has been associated with delayed disease progression underscores the importance of host factors in the clinical course of HIV-1 infection, addresses fundamental issues in our understanding of the susceptibility, resistance and pathogenesis of several diseases and consolidates the importance of therapeutic intervention with combinations of chemokine receptor inhibitors to improve the antiretroviral therapeutic effects.

\section{Acknowledgements}

We thank the Health Ministry, Brazilian National Sexually Transmitted Disease/AIDS Program (CN-DST/AIDS), for their financial support with the cooperative agreement of the Londrina State University (Grants UNESCO-UEL CFA 667/01), the Londrina University Hospital for technical and administrative support, and the PIBIC-CNPq Program for student grants.

\section{References}

1. Bates I, Fenton C, Gruber J, Lalloo D, Lara M, Squire SB, Theobald S, Thomson R and Tolhurst R: Vulnerability to malaria, tuberculosis, and HIV/AIDS infection and disease. Part 1: determinants operating at individual and household level. Lancet 4: 267-277, 2004.

2. Pantaleo G, Graziosi C, Demarest JF, Butini L, Montroni M, Fox CH, Orenstein JM, Kotler DP and Fauci AS: HIV infection is active and progressive in lymphoid tissue during the clinically latent stage of disease. Nature 362: 355-358, 1993.

3. Hogan $\mathrm{C}$ and Hammer S: Host determinants in HIV infection and disease: Part 1: cellular and humoral responses. Ann Intern Med 134: 761-776, 2001.

4. Hogan C and Hammer S: Host determinants in HIV infection and disease: Part 2: genetic factors and implications for antiretroviral therapeutics. Ann Intern Med 134: 978-996, 2001.

5. Evans DT and Desrosiers RC: Immune evasion strategies of the primate lentiviruses. Immunol Rev 183: 141-158, 2001.

6. Dean M, Carrington M, Winkler C, Huttley GA, Smith MW, Allikmets R, Goedert JJ, Bichbinder SP, Vittinghoff E, Gomperts E, Donfield S, Vlahov D, Kaslow R, Saah A, Rinaldo C, Detels R and O'Brien SJ: Genetic restriction of HIV-1 infection and progression to AIDS by a deletion allele of the CKR5 structural gene. Science 273: 1856-1862, 1996.

7. Liu R, Paxton WA, Choe S, Ceradini D, Martin SR, Horuk R, MacDonald ME, Stuhlmann H, Koup RA and Landau NR: Homozygous defect in HIV-1 coreceptor accounts for resistance of some multiply-exposed individuals to HIV-1 infection. Cell 86: 367-377, 1996.

8. Sams on M, Libert F, Doranz BJ, Rucker J, Liesnard C, Farber CM, Saragosti S, Lapoumeroulie C, Cognaux J, Forceille CM, Muylderman G, Verhofstede C, Burtonboy G, Georges M, Imai T, Rana S, Yi Y, Smyth RJ, Collman RG, Doms RW, Vassart G and Parmentier M: Resistance to HIV-1 infection in Caucasian individuals bearing mutant alleles of the CCR-5 chemokine receptor gene. Nature 382: 722-725, 1996.

9. Zimmerman P, Bucker-White A, Alkhatib G, Spalding T, Kubofcik J, Combadiere C, Weissman D, Cohen O, Rubbert A, Lam G, Vaccarezza M, Kennedy PE, Kumaraswami V, Giorgi JV, Detels R, Hunter J, Chopek M, Berger EA, Fauci AS, Nutman TB and Murphy PM: Inherited resistance to HIV-1 conferred by an inactivating mutation in $\mathrm{CC}$ chemokine receptor 5: studies in populations with contrasting clinical phenotypes, defined racial background, and quantified risk. Mol Med 3: 23-36, 1997.

10. Huang Y, Paxton WA, Wolinksy SM, Wolinsky SM, Neumann AU, Zhang L, He T, Ceradini D, Jin Z, Yazdanbakhsh K, Kunstman K, Erickson D, Dragon E, Landau NR, Phair J, Ho DD and Koup RA: The role of a mutant CCR5 allele in HIV-1 transmission and disease progression. Nat Med 2: 1240-1243,1996.

11. Smith MW, Dean M, Carrington M, Winkler C, Huttley GA, Lomb DA, Goedert JJ, O'Brien TR, Jacobson LP, Kaslow R, Buchbinder S, Vittinghoff E, Vlahov D, Hoots K, Hilgartner MW and O'Brien SJ: Contrasting genetic influence of CCR2 and CCR 5 variants on HIV-1 infection and disease progression. Science 277: 959-965, 1997. 
12. Martin MP, Dean M, Smith MW, Winkler C, Gerard B, Michael NL, Lee B, Doms RW, Margolick J, Buchbinder S, Goedert JJ, O'Brien TR, Hilgartner MW, Vlahov D, O'Brien SJ and Carrington M: Genetic acceleration of AIDS progression by a promoter variant of CCR5. Science 282: 1907-1911, 1998.

13. de Roda Husman AM, Koot M, Cornelissen M, Keet IPM, Brouwer M, Broersen SM, Bakker M, Roos MTL, Prins M, de Wolf F, Coutinho RA, Miedema F, Goudsmit J and Schuitemaker H: Association between CCR5 genotype and the clinical course of HIV-1 infection. Ann Intern Med 127: 882-890, 1997.

14. Meyer L, Magierowska M, Hubert J-B, Theodorou I, van Rij R, Prins M, de Roda Husman A-M, Coutimho R and Schuitemaker H: CC-chemokine receptor variants, SDF-1 polymorphism, and disease progression in $720 \mathrm{HIV}$-infected patients. AIDS 13: 624-626, 1999.

15. Ioannidis JP, O'Brien TR, Rosenberg PS, ContopoulosIoannidis DG and Goedert JJ: Genetic effects on HIV disease progression. Nat Med 4: 536, 1998.

16. Ioannidis JPA, Rosenberg PS, Goedert JJ, Ashton LJ, Benfield TL, Buchbinder SP, Coutinho RA, Eugen-Olsen J, Gallart T, Katzenstein TL, Kostrikis LG, Kuipers H, Louie LG, Mallal SA, Margolick JB, Martinez OP, Meyer L, Michael NL, Operskalski E, Pantaleo G, Rizzardi GP, Schuitemaker H, Sheppard HW, Stewart GJ, Theodorou ID, Ullum H, Vicenzi E, Vlahov D, Wilkinson D, Workamn C, Zagury J-F and O'Brien TR: Effects of CCR5 [Delta]32, CCR2-64I, and SDF-1 3'A alleles on HIV disease progression: an international metaanalysis of individual-patient data. Ann Intern Med 135: 782-795, 2001.

17. Cohen OJ, Kinter A and Fauci AS: Host factors in the pathogenesis of HIV disease. Immunol Rev 159: 31-48, 1997.

18. Eugen-Olsen J, Iversen AKN, Garred P, Koppelhus U, Pedersen C, Benfield TL, Sorensen AM, Ktzenstein T, Dickmeiss E, Gerstoft J, Skinhoj P, Svejgaard A, Nielsen JO and Hofmann B: Heterozygosity for a deletion in the CKR-5 gene leads to prolonged AIDS-free of HIV-seropositive individuals. AIDS 11: 305-310, 1997.

19. Apostolakis S, Baritaki S, Krambovitis E and Spandidos DA: Distribution of HIV/AIDS protective SDF1, CCR5 and CCR2 gene variants within Cretan population. J Clin Virol 34: 310-314, 2005.

20. Martinson JJ, Chapman NH, Rees DC, Liu YT and Clegg JB: Global distribution of the CCR5 gene 32 base-pair deletion. Nat Genet 16: 100-103, 1995.

21. Libert F, Cochaux P, Beckman G, Samson M, Aksenova M, Cao A, Czeizel A, Claustres M, de la Rúa C, Ferrari M, Ferrec C, Glover G, Grinde B, Güran S, Kucinskas V, Lavinha J, Mercier B, Ogur G, Peltonen L, Rosatelli C, Schwartz M, Spitsyn V, Timar L, Beckman L, Parmentier M and Vassart G: The delta CCR5 mutation conferring protection against HIV-1 in Caucasian population has a single and recent origin in Northeastern Europe. Hum Mol Genet 7: 399-406, 1998.

22. Lu Y, Nerurkar VR, Dashwood WM, Woodward CL, Ablan S, Shikuman CM, Grandinetti A, Chang H, Nguyen HT, Wu Z, Yamamura Y, Boto WO, Merriwether A, Kurata T, Detels R and Yanagihaa R: Genotype and allele frequency of a 32-base pair deletion mutation in the CCR5 gene in various ethnic groups: absence of mutation among Asians and Pacific Islanders. Int J Infect Dis 3: 186-191, 1999.

23. Nookhai S, Ruxrungtham K, Phanuphak P and Oelrichs R: Prevalence of CCR2-64I, SDF1-3'A and CCR5- $\triangle 32$ alleles in healthy Thais. Eur J Immunogenet 27: 153-157, 2000.

24. Gharagozloo M, Doroudchi M, Farjadian S, Pezeshki AM and Ghaderi A: The frequency of CCR5- $\triangle 32$ and CCR2-64I in southern Iranian normal population. Immunol Lett 96: 277-281, 2005.

25. Salem A-H and Batzer MA: Distribution of the HIV resistance CCR5- $\Delta 32$ allele among Egyptians and Syrians. Mutat Res 616 : 175-180, 2007.

26. Diaz FJ, Vega JA, Patino PJ, Bedoya G, Nagles J, Villegas C, Vesga R and Rugeles MT: Frequency of CCR5 delta-32 mutation in human immunodeficiency virus (HIV)-seropositive and HIVexposed seronegative individuals and in general population of Medelin, Colombia. Mem Inst Oswaldo Cruz 95: 237-242, 2000.

27. Passos GA Jr and Picanco VP: Frequency of the delta CCR5 deletion allele in the urban Brazilian population. Immunol Lett 61: 205-207, 1998
28. Leboute APM, Carvalho MWO and Simões AL: Absence of the delta CCR5 mutation in indigenous populations of the Brazilian Amazon. Hum Genet 105: 442-443, 1999.

29. Grimaldi R, Shindo N, Acosta AX, Dourado I, Brites C, Carvalho O de, Brito I, Bou-Habib DC and Galvão-Castro B: Prevalence of the CCR5- $\Delta 32$ mutation in Brazilian populations and cell susceptibility to HIV-1. Hum Genet 111: 102-104, 2002.

30. Vargas AE, Marrero AR, Salzano FM, Bortolini MC and Chies JAB: Frequency of CCR5- $\triangle 32$ in Brazilian populations. Braz J Med Biol Res 39: 321-325, 2006.

31. UNAIDS - Joint United Nations Programme on HIV/AIDS. AIDS epidemic update: special report on HIV/AIDS: December 2007.

32. Brazil. Ministry of Health. National Coordination of Sexually Transmitted Diseases (STD) and AIDS. 1 ${ }^{\mathrm{a}}$. a 26 ${ }^{\mathrm{a}}$. semanas epidemiológicas- January-June, 2006. Boletim Epidemiológico AIDS 1: 3-49, 2006. (in Portuguese)

33. Reiche EMV, Bonametti AM, Watanabe MAE, Morimoto HK, Morimoto AA, Wiechmann SL, Breganó JW, Matsuo T and Reiche FV: Socio-demographic and epidemiological characteristics associated with human immunodeficiency virus type 1 (HIV-1) infection in HIV-1-exposed but uninfected individuals, and in HIV-1-infected patients from a southern Brazilian population. Rev Inst Med Trop Sao Paulo 47: 239-246, 2005.

34. Reiche EMV, Watanabe MAE, Bonametti AM, Morimoto HK, Morimoto AA, Wiechamnn SL, Matsuo T, Miranda HC, Reiche FV and Oliveira KB: Stromal cell-derived factor 1 (SDF1) genetic polymorphism in a sample of healthy individuals, seronegative individuals exposed to human immunodeficiency virus type 1 (HIV-1) and patients infected with HIV-1 from the Brazilian population. Int J Immunogenet 33: 127-133, 2006.

35. Reiche EMV, Watanabe MAE, Bonametti AM, Morimoto HK, Morimoto AA, Wiechamnn SL, Breganó JW, Matsuo T, Reiche FV, Miranda HC, Oliveira KB, Vogler IH and Siscar AR: The effect of stromal cell-derived factor 1 (SDF1/CXCL12) genetic polymorphism on HIV-1 disease progression. Int J Mol Med 18: 785-793, 2006.

36. CDC. Center for Disease Control and Prevention. Revised guidelines for HIV counseling, testing, and referral and revised recommendations for HIV screening of pregnant women. Morb Mortal Wkly Rep 50: 8-9, 2001.

37. Brazil. Ministry of Health. National Coordination of Sexually Transmitted Diseases (STD) and AIDS. Recomendações para Terapia anti-retroviral em adultos e adolescentes infectados pelo HIV 2002/2003, Brasília, 2002. URL: http://www.aidsw.gov.br Captured in 27/12/2002, 2002. (in Portuguese)

38. Brazil. Ministry of Health. National Coordination of Sexually Transmitted Diseases (STD) and AIDS. Revisão da Definição Nacional de Caso de AIDS em indivíduos com 13 anos ou mais, para fins de vigilância epidemiológica. Brasília: Ministry of Health, 1998. (in Portuguese)

39. Brazil. Ministry of Health. Agência Nacional de Vigilância Sanitária. Portaria no. 488 de 17 de junho de 1998, 1998. (in Portuguese)

40. Miller SA, Dykes DD and Polesky HF: A simple salting out procedure for extracting DNA from human nucleated cells. Nucleic Acid Res 16: 1215-1219, 1988.

41. Dean AG, Dean JA, Coulombier D, Brendel KA, Smith DC, Burton AH, Dicker RC, Sullivan K, Fagan RF and Arner TG: Epi Info, Version 6.0: World-processing database, and statistics program for Public Health on IBM-compatible microcomputers. Centers for Disease Control and Prevention, Atlanta, Georgia, 1995.

42. SAS Institute Inc. SAS/STAT User's Guide, Version 6, Fourth Edition, Cary, NC: SAS Institute Inc., 1989.

43. Trecarichi EM, Tumbarello M, de Gaetano Donati K, Tamburrini E, Cauda R, Brahe C and Tiziano FD: Partial protective effect of CCR5-Delta 32 heterozygosity in a cohort of heterosexual Italian HIV-1 exposed uninfected individuals. AIDS Res Ther 3: 22, 2006.

44. Alves-Silva J, Santos MS, Guimarães PEM, Ferreir ACS, Bandelt H-J, Pena SDJ and Prado VF: The ancestry of Brazilian mtDNA lineages. Am J Hum Genet 67: 444-461, 2000.

45. Mikawa AY, Tagliavini SA and Costa PI: CCR5 genotype and plasma $\beta$-chemokine concentration of Brazilian HIV-infected individuals. Braz J Med Biol Res 35: 1333-1337, 2002.

46. Rugeles MT, Solano F, Díaz FJ, Bedoya VI and Patiño PJ: Molecular characterization of the CCR 5 gene in seronegative individuals exposed to human immunodeficiency virus (HIV). J Clin Virol 23: 161-169, 2002. 
47. Suresh P, Wanchu A, Sachdeva RK and Bhatnagar A: Gene polymorphism in CCR5, CCR2, CXCR3, SDF1 and RANTES in exposed but uninfected partners of HIV-1 infected individuals in North India. J Clin Immunol 26: 476-484, 2006.

48. Reiche EM, Bonametti AM, Voltarelli JC, Morimoto HK and Watanabe MAE: Genetic polymorphisms in the chemokine and chemokine receptors: impact on clinical course and therapy of the human immunodeficiency virus type 1 infection (HIV-1). Curr Med Chem 14: 1325-1334, 2007.

49. Lama J and Planelles V: Host Factors influencing susceptibility to HIV infection and AIDS progression. Retrovirology 4: 52, 2007.

50. Haynes BF, Pantaleo G and Fauci AS: Toward an understanding of the correlates of protective immunity to HIV infection. Science 271: 324-328, 1996

51. Costello C, Tang J, Rivers C, Karita E, Meiaen-Derr J, Allen S and Kaslow RA: HLA-B*5703 independently associated with slower HIV-1 disease progression in Rwandan women. AIDS 13: 1990-1991, 1999

52. Carrington M, Nelson GW, Martin MP, Kissner T, Vlahov D, Goedert JJ, Kaslow R, Buchbinder S, Hoots K and O'Brien SJ: HLA and HIV-1: heterozygosity advantage and B*35-Cw*04 disadvantage. Science 283: 1748-1752, 1999.

53. Clerici M, Giorgi JV, Chou CC, Gudeman VK, Zack JA, Gupta P, Ho H-N, Nishanian PG, Berzofsky JA and Shearer GM: Cellmediated immune response to human immunodeficiency virus (HIV) type 1 in seronegative homosexual men with recent sexual exposure to HIV-1. J Infect Dis 165: 1012-1019, 1992.

54. Langlade-Demoyen P, Ngo-Giang-Huong N, Ferchal F and Oksenhendler E: Human immunodeficiency virus (HIV) nefspecific cytotoxic $\mathrm{T}$ lympohocytes in noninfected heterosexual contact of HIV-infected patients. J Clin Invest 93: 1293-1297, 1994.
55. Plummer FA, Ball TB, Kimani J and Fowke KR: Resistance to HIV-1 infection among highly exposed sex workers in Nairobi: what mediates protection and why does it develop? Immunol Lett 66: 27-34, 1999.

56. Fowke KR, Nagelkerke NJD, Kimani J, Simonses JN, Anzala AO, Bwayo JJ, MacDonald KS, Ngugi EN and Plummer FA: Resistance to HIV-1 infection among persistently seronegative prostitutes in Nairobi, Kenya. Lancet 348: 1347-5131, 1996.

57. Rowland-Jones SL, Nixon DF, Aldhous MC, Aldhous MC, Gotch F, Atiyoshi K, Hallam N, Kroll JS, Froebel K and McMichael A: HIV-specific cytotoxic T-cell activity in an HIVexposed but uninfected infant. Lancet 341: 860-861, 1993.

58. Bernard NF, Yannakis CM, Lee JS and Tsoukas CM: Human immunodeficiency virus (HIV)-specific cytotoxic T lymphocyte activity in HIV-exposed seronegative persons. J Infect Dis 179: 538-547, 1999.

59. Goh WC, Markee J, Akridge RE, Meldorf M, Musey L, Karchmer T, Krone M, Collier A, Corey L, Emerman M and McElrath MJ: Protection against human immunodeficiency virus type 1 infection in persons with repeated exposure: evidence for $\mathrm{T}$ cell immunity in the absence of inherited CCR5 coreceptor defects. J Infect Dis 179: 548-557, 1999.

60. Reynes J, Portales P, Segondy M, Baillat V, André P, Réant B, Avinens O, Couderc G, Benkirane M, Clot J, Eliaou JF and Corbeau P: $\mathrm{CD}^{+} \mathrm{T}$ cell surface CCR5 density as a determining factor of virus load in persons infected with human immunodeficiency virus type 1. J Infect Dis 181: 927-932, 2000.

61. Michael NL, Louie LG, Rohrbaugh AL, Schultz KA, Dayhoff DE, Wang CE and Sheppard HW: The role of CCR5 and CCR2 polymorphisms in HIV-1 transmission and disease progression. Nat Med 3: 1160-1162, 1997. 